\title{
PLUTAJUĆI TERMINAL ZA UKAPLJENI PRIRODNI PLIN NA OTOKU KRKU - PRAVNI ASPEKTI ZAŠTITE MORSKOG OKOLIŠA S NAGLASKOM NA MEĐUNARODNO PRAVO
}

Irena Nišević, mag. iur.*

UDK: $341.225 .5 / .8: 665.61(497.5)$

347.793:665.61(497.5)

DOI: $10.3935 / z p f z .70 .1 .05$

Pregledni znanstveni rad

Primljeno: veljača 2020.

U radu se obrađuju pravni aspekti utjecaja djelatnosti plutajućeg terminala na morski okoliš, i to u fazi kada terminal počne raditi, što se predviđa za I. siječnja 2021. godine, ne ulazeći u analizu utjecaja gradnje samog terminala na morski okoliš. Djelatnosti plutajućeg terminala su prihvat, skladištenje i uplinjavanje ukapljenog prirodnog plina te zatim otprema prirodnog plina u transportni sustav. Unatoč primjeni dužne pažnje ove djelatnosti mogu dovesti do štetnih posljedica za morski okoliš. U slučaju da te djelatnosti s povećanom opasnošću prouzroče onečišćenje morskog okoliša, odgovara osoba koja se njima bavi, osim ako se ugovorom kojim se operater ovlašćuje na obavljanje takvih djelatnosti izričito ne propiše odgovornost države pod čijom jurisdikcijom ili kontrolom se djelatnosti obavljaju.

Ključne riječi: plutajući terminal; ukapljeni prirodni plin; onečišćenje morskog okoliša; djelatnosti s povećanom opasnošću; odgovornost države bez protupravnosti

\section{UVOD}

Terminal za ukapljeni prirodni plin (dalje u tekstu: UPP), odnosno engl. Liquified Natural Gas (dalje u tekstu: LNG) Terminal je terminal za prihvat, skladištenje i uplinjavanje UPP-a te za isporuku prirodnog plina u plinovodnu

* Irena Nišević, mag. iur., asistentica Jadranskog zavoda Hrvatske akademije znanosti i umjetnosti, Šenoina 4, Zagreb; irena.crnjak@gmail.com;

ORCID ID: orcid.org/0000-0002-8763-8159 
mrežu. ${ }^{1}$ Pritom se prihvat odnosi na prihvaćanje brodova koji prevoze UPP, za što se u zadnje vrijeme, uz kopnene terminale, koriste i plutajući terminali, i to sve više u obliku tzv. FSRU jedinica. ${ }^{2}$ Nakon iskrcaja UPP-a on se privremeno skladišti kako bi se mogao dalje postupno pretvarati u plinovito stanje s potrebnim tlakom za puštanje u plinovodnu mrežu do krajnjeg korisnika. Uzimajući u obzir prirodna svojstva UPP-a, koji je zapravo bezbojna tekućina uglavnom sastavljena od metana, a prevozi se u brodskim spremnicima brodova za prijevoz UPP-a ohlađen na temperaturi od -162 Celzijeva stupnja do prihvatnih terminala, rukovođenje djelatnostima u ovom složenom procesu zahtijeva pažnju odgovornih osoba i korištenje odgovarajuće zaštitne opreme kako bi se izbjegle ozebline s fatalnim posljedicama i oštećenje imovine.

Iako u tekućem stanju nije zapaljiv, ipak u slučaju izlijevanja UPP-a iz spremnika postoji opasnost od eksplozije ili požara jer bi ubrzo nakon izlijevanja uslijedilo isparavanje, a upravo nepovoljan omjer plina i kisika može dovesti do takvih nekontroliranih kemijskih reakcija, doduše uslijed isparavanja u zatvorenom prostoru. Međutim, već sama izrazita vrućina koja bi nastala od isparenog plina predstavljala bi opasnost za zdravlje ljudi koji bi i kratkotrajnim izlaganjem takvoj vrućini zadobili teške opekline. Slijedom navedenog, opisane djelatnosti vezane uz rad plutajućeg terminala prepoznate su u međunarodnome pravu kao djelatnosti s povećanom opasnošću, o čemu će više riječi biti infra 7.1.1.

Sam projekt izgradnje terminala za UPP u općini Omišalj na otoku Krku razvija se u dvije faze: izgradnja plutajućeg te izgradnja kopnenog terminala. Osim energetske neovisnosti Republike Hrvatske, cilj ovog strateškog investicijskog projekta $^{3}$ je i kontinuirana te sigurna opskrba putem novog opskrbnog pravca

1 Pobližu definiciju terminala za UPP nudi čl. 3. t. 8. Zakona o terminalu za ukapljeni prirodni plin (Narodne novine, br. 57/2018) koji ga opisuje kao "terminal koji se koristi za ukapljivanje prirodnog plina ili prihvat, iskrcaj i ponovno uplinjavanje UPP-a, uključujući pomoćne usluge i privremeno skladištenje potrebno za postupak ponovnog upljivanjavanja i daljnju otpremu u transportni sustav, ali isključujući dijelove terminala za UPP koji se koriste za skladištenje”. (dalje u tekstu: ZTUPP).

2 FSRU (engl. Floating storage and regasification unit) jedinica je usidrena kraj luke te prihvaća UPP, odnosno u njoj se UPP skladišti, pretvara u plinovito stanje i onda se dalje transportira u plinovodnu mrežu. Za FSRU u ovom projektu društvo LNG Hrvatska d. o. o., kao ovlaštenik koncesije, odabralo je ponudu norveškog društva Golar Power Limited, i to LNG tanker proizveden 2005. godine koji plovi pod imenom "Golar Viking”, koji će se konvertirati iz tankera u FSRU.

3 U prilog činjenici da je riječ o strateškom investicijskom projektu, kako je i izričito propisano u čl. 4. ZTUPP-a, govori i Odluka Vlade Republike Hrvatske od 30. siječnja 2019. godine o financiranju prve faze projekta plutajućeg terminala za ukapljeni prirodni plin na otoku Krku na temelju koje su dodijeljena bespovratna sredstva u 
prirodnog plina za zemlje srednje i jugoistočne Europe. S druge strane, lokalno stanovništvo u naseljima Omišalj i Njivice na otoku Krku izražava bojazan u odnosu na moguće štetne posljedice rada terminala na morski okoliš, a time podredno i na lokalno gospodarstvo, napose turizam i ribarstvo. ${ }^{4}$

Budući da bi plutajući terminal trebao doprinijeti gospodarskom rastu Republike Hrvatske, valja učiniti sve kako bi se zadani ciljevi ostvarili uz što manju ili, u idealnom slučaju, nikakvu štetu za morski okoliš. Zagovornici izgradnje plutajućeg terminala reći će da nema gospodarskog napretka bez nekog odricanja s druge strane, pa makar i na račun određene štete za morski okoliš unutar prihvatljivih granica. Pogotovo kada se analizira utjecaj različitih izvora na onečišćenje morskog okoliša, iz čega proizlazi da otprilike $80 \%$ onečišćenja mora zapravo potječe s kopna ${ }^{5}$, primjerice od kućnog otpada, kanalizacije ili industrijskog onečišćenja, a ne od, kao što bi se možda očekivalo, brodova s kojih se izlije nafta u more ili, u ovom slučaju, od opisanih djelatnosti proizašlih iz rada plutajućeg terminala za UPP.

Obrađujući pitanja zaštite morskog okoliša, ponajprije valja razmotriti obveze država propisane Konvencijom Ujedinjenih naroda o pravu mora ${ }^{6}$ kao "krovnom konvencijom" u tom području, i to u njezinu dijelu XII. Iako Konvencija iz 1982. ne nudi samu definiciju pojma "morski okoliš”, ipak u čl. l. st. 4. definira onečišćenje morskog okoliša kao “čovjekovo izravno ili neizravno unošenje tvari ili energije u morski okoliš, uključujući estuarije, koje uzrokuje ili može prouzročiti takve pogubne posljedice kao što su šteta živim bogatstvima i životu u moru, ugrožavanje ljudskog zdravlja, ometanje pomorskih djelatnosti, uključujući ribolov i druge zakonite upotrebe mora, pogoršanje upotrebne kvalitete morske vode i umanjenje privlačnosti”.

iznosu od 100 milijuna eura, uz to što je i Europska komisija dodijelila bespovratna sredstva u iznosu od 101,4 milijuna eura. Ukupna vrijednost projekta plutajućeg terminala je 234 milijuna eura.

4 https://vijesti.hrt.hr/490883/omisalj-zagovornici-i-protivnici-lng-a (3. prosinca 2019.).

5 https://www.unenvironment.org/explore-topics/oceans-seas/what-we-do/addressing-land-based-pollution (3. prosinca 2019.).

6 Narodne novine, Međunarodni ugovori, br. 9/2000, dalje u tekstu: Konvencija iz 1982. Treća konferencija Ujedinjenih naroda o pravu mora usvojila je tekst Konvencije i ona je otvorena za potpisivanje 10. prosinca 1982. godine u Montego Bayu, Jamajka, a stupila je na snagu 16. studenoga 1994. godine. Republika Hrvatska priopćila je glavnom tajniku Ujedinjenih naroda 5. travnja 1995. godine svoju odluku o tome da želi biti sljednicom ratifikacije od SFRJ.

7 Rudolf, D., Enciklopedijski rječnik međunarodnoga prava mora, Matica hrvatska, Zagreb, 2012., str. 450. 
Uzimajući u obzir nabrojene štetne posljedice koje bi mogle biti uzrokovane djelatnostima plutajućeg terminala, valjalo bi primijeniti odgovarajuće međunarodnopravne mehanizme u svrhu sprječavanja nastanka štetnih posljedica za morski okoliš, odnosno njihova smanjivanja i nadziranja. Ako do štete ipak dođe, preostalo bi utvrditi odgovornost za onečišćenje, odnosno obvezu naknade štete. Stoga se u ovome radu daje osvrt na obvezu prevencije, zatim intervencije te potom popravljanja štete uzrokovane djelatnostima vezanim uz rad plutajućeg terminala.

\section{PRAVNI STATUS PLUTAJUĆEG TERMINALA U HRVATSKOM ZAKONODAVSTVU}

Prvi korak od kojega valja poći pri analizi utjecaja rada plutajućeg terminala na morski okoliš te zaštiti morskog okoliša s tim u vezi jest uopće utvrditi pravni status plutajućeg terminala. Sukladno čl. 5. t. 29. Pomorskog zakonika ${ }^{8}$ plutajući terminal je obuhvaćen pojmom plutajućeg objekta, koji je definiran kao "pomorski objekt stalno privezan ili usidren na moru, koji nije namijenjen za plovidbu”. Također, zajedno s plovnim objektima i nepomičnim odobalnim objektima svrstan je u kategoriju pomorskih objekata. ${ }^{9}$ Tako je na temelju odredaba PZ-a o zaštiti od onečišćenja s pomorskih objekata ${ }^{10}$ operater plutajućeg objekta obvezan poštovati međunarodne, europske i hrvatske propise i standarde o zaštiti od onečišćenja mora i zraka s pomorskih objekata, a ako dođe do onečišćenja mora, zraka ili obale, dužan je bez odgađanja izvijestiti Ministarstvo nadležno za pomorstvo koje će "odmah izvršiti očevid ... te prema okolnostima slučaja pokrenuti prekršajni postupak i/ili podnijeti kaznenu prijavu..." ${ }^{11}$ Utvrđena prekršajna i/ili kaznena odgovornost može biti i značajna okolnost pri utvrđivanju odštetne odgovornosti na koju se, pak, primjenjuju opći propisi obveznog prava, o čemu će više riječi biti infra 7.2.

Nadalje, na temelju čl. 3. t. 1. Pravilnika o plutajućim objektima ${ }^{12}$ plutajući terminal pobliže je određen kao "pristan - plutajući objekt namijenjen pristajanju drugih plovila i opremljen uređajima za vez, snabdijevanje i prekrcaj tereta". Potonjim Pravilnikom ujedno se određuje način utvrđivanja sposobnosti plutaju-

8 Narodne novine, br. 181/2004, 76/2007, 146/2008, 61/2011, 56/2013, 26/2015 i 17/2019, dalje u tekstu: PZ.

9 Čl. 5. t. 31. PZ-a.

10 Glava I. a PZ-a.

11 Čl. 49. f PZ-a.

12 Narodne novine, br. 72/2015 i 83/2015. 
ćeg objekta za uporabu, pregled i nadzor, najmanji broj i stručna osposobljenost brodaraca na plutajućim objektima, isprave i knjige te oznake plutajućeg objekta. Sam objekt upisuje se u Očevidnik plutajućih objekata mjesno nadležne lučke kapetanije.

Nakon tako utvrđenog pravnog statusa plutajućeg terminala potrebno je primijeniti odgovarajuće međunarodnopravne mehanizme zaštite morskog okoliša od štetnih posljedica djelatnosti s povećanom opasnošću vezanih uz rad plutajućeg terminala. To je posebice važno s obzirom na to da je najbliža točka granice s najbližom susjednom državom udaljena od terminala 33 kilometra pa prekogranični utjecaj rada plutajućeg terminala posebno može doći do izražaja u slučajevima eksplozije ili požara koji zapravo predstavljaju najveći i pravi rizik tijekom rada plutajućeg terminala.

\section{MEĐUNARODNOPRAVNI OKVIR ZA UREĐENJE ZAŠTITE MORSKOG OKOLIŠA OD DJELATNOSTI VEZANIH UZ RAD PLUTAJUĆEG TERMINALA}

Uzimajući u obzir opasnosti koje sa sobom nosi prijevoz i rukovanje UPP-om, potrebno je osigurati pravni okvir za obavljanje gospodarskih djelatnosti vezanih uz rad plutajućeg terminala uz poštovanje standarda zaštite morskog okoliša te sigurnosti ljudi i imovine.

U prilog tome govori i važnost tih djelatnosti za svjetsko gospodarstvo, primjerice, prijevoza UPP-a, uzimajući u obzir da međunarodni prijevoz robe morem, kao najučinkovitiji i najjeftiniji način međunarodnog prijevoza robe, čini više od $80 \%$ svjetske trgovine. ${ }^{13}$

Unatoč činjenici što danas postoji velik broj međunarodnih ugovora koji uređuju zaštitu morskog okoliša, što pokazuje ozbiljnost u prepoznavanju i obradi pitanja sprječavanja, smanjivanja i nadziranja onečišćenja, ipak valja primijetiti da se ta pitanja, zbog množine instrumenata koja ih uređuju, neusklađeno obrađuju i u konačnici dovode i do pravnih praznina. ${ }^{14}$

Tako ni odgovarajući međunarodnopravni standardi zaštite morskog okoliša vezani uz rad plutajućeg terminala za sada nisu uređeni jedinstvenim međunarodnim ugovorom ni na svjetskoj ni na regionalnoj razini. Birajući između najispravnijeg pristupa uređenju tog pitanja, postavlja se pitanje na kojoj od navedenih razina je prikladnije urediti to pitanje, odnosno je li uopće ispravno

13 http://www.imo.org/en/About/Pages/Default.aspx (3. prosinca 2019.).

14 Degan, V. Đ., Međunarodno pravo, Školska knjiga, Zagreb, 2011., str. 396. 
urediti ga isključivo na jednoj od razina. Pogotovo uzimajući u obzir općeniti međuodnos globalnih i regionalnih međunarodnih ugovora. Naime, globalni međunarodni ugovori često potiču usvajanje pravila na regionalnoj razini, dok potonji utječu na oblikovanje odredaba međunarodnih ugovora sklopljenih na svjetskoj razini. ${ }^{15}$

Iako je onečišćenje morskog okoliša prepoznato kao globalni problem, pa su tako na svjetskoj razini usvojeni međunarodni ugovori koji uređuju pojedine izvore onečišćenja, primjerice Međunarodna konvencija o sprječavanju onečišćenja mora s brodova iz 1973. godine koja je na snazi izmijenjena Protokolom iz 1978. godine ${ }^{16}$, ipak se u drugim slučajevima regionalni pristup onečišćenju morskog okoliša pokazao učinkovitijim. Naime, na taj način se uzimaju u obzir posebne značajke određenog mora, poput dubine, temperature, morskih struja, prometne važnosti i/ili zemljopisnog položaja. Osim toga, omogućuje se potpuna uključenost odnosnim obalnim državama u oblikovanje odgovarajućih mehanizama zaštite regionalnog mora od onečišćenja. Uostalom, one imaju više interesa sudjelovati u regionalnim međunarodnim ugovorima jer su rezultati mjera poduzetih u okviru tako sklopljenih ugovora neposredno vidljivi na njihovim obalama $\mathrm{u}$ usporedbi s međunarodnim ugovorima sklopljenima na svjetskoj razini koji često zahtijevaju duge pregovore i nerijetko dovode do (apstraktnih) rješenja problema od kojih pojedine države nemaju izravne koristi. Stoga se, s obzirom na zemljopisni položaj Jadranskog mora, koje sukladno čl. 122. Konvencije iz $1982 .{ }^{17}$ potpada pod definiciju poluzatvorenih mora, regionalno uređenje zaštite morskog okoliša pokazuje učinkovitim pristupom.

U svrhu određivanja primjenjivih međunarodnih ugovora na FSRU jedinicu, potonju je potrebno razvrstati ili u kategoriju broda ili pak plutajućeg objekta. Takva klasifikacija ovisi o namjeni FSRU jedinice, dakle o tome je li ona namijenjena samostalnoj plovidbi, u kojem slučaju je riječ o brodu, ili pak, unatoč svojoj sposobnosti za plovidbu, nije namijenjena plovidbi, pa govorimo o plutajućem objektu. Plutajući terminal za UPP ima višestruku namjenu, od kojih su

15 Boczek, B. A., Global and Regional Approaches to the Protection and Preservation of the Marine Environment, Case Western Reserve Journal of International Law, vol. 16, 1984., str. 68.

16 Na temelju notifikacije o sukcesiji Republika Hrvatska stranka je navedene Konvencije od 8. listopada 1991., Narodne novine, Međunarodni ugovori, br. 1/1992, dalje u tekstu: MARPOL konvencija.

17 Čl. 122. Konvencije iz 1982. godine glasi: "U svrhe Konvencije 'zatvoreno ili poluzatvoreno more' znači zaljev, bazen ili more okruženo s dvije ili više država i povezano s drugim morem ili oceanom uskim prolazom, ili koje se u cijelosti ili pretežito sastoji od teritorijalnih mora i isključivih gospodarskih pojaseva dviju ili više obalnih država". 
izdvojene prihvat, skladištenje, uplinjavanje i isporuka plina te bi rukovanje tim postupcima u prvom redu trebalo biti u skladu s odredbama o sigurnosti, među ostalim glede konstrukcije i opreme. Potonje odredbe sadržava Međunarodna konvencija o zaštiti ljudskih života na moru iz 1974. godine s amandmanima. ${ }^{18}$ Međutim, ista konvencija isključuje fiksnu FSRU jedinicu iz područja svoje primjene, upravo zbog izostanka namjene plovidbe, odnosno kako se navodi u njezinu Pravilu 3., da su isključeni brodovi bez mehaničkog pogona ("ships not propelled by mechanical means”). Posljedično, na FSRU jedinicu ne primjenjuje se ni Kodeks o gradnji i opremi brodova za prijevoz ukapljenih plinova u trupu koji je dio SOLAS konvencije. ${ }^{19}$

Među najznačajnije međunarodne ugovore koji uređuju pitanja zaštite morskog okoliša vezano uz rad plutajućeg terminala preostaje razmotriti odredbe MARPOL konvencije koja u čl. 2. st. 4. navodi da brod znači "plovilo bilo koje vrste koje djeluje u morskom okolišu i uključuje hidrokrilna plovila, lebdjelice, podmornice, plutajuće objekte i fiksne ili plutajuće platforme”. Slijedom navedenog, neki autori smatraju da se MARPOL konvencija primjenjuje i na fiksne FSRU jedinice ${ }^{20}$, dakako samo u odnosu na prevenciju onečišćenja morskog okoliša, s obzirom na to da konvencija u definiciju broda ne uključuje samo one objekte koji plove, odnosno koji se kreću na motorni pogon. Sličnu definiciju donosi i čl. 2. st. 9. Međunarodne konvencije o nadzoru štetnih sustava protiv obraštanja brodova iz 2001. godine. ${ }^{21}$

U nastavku ovog rada analiziraju se odredbe međunarodnih ugovora koje su mjerodavne uzimajući u obzir pravnu prirodu plutajućeg terminala u širem smislu, pri čemu bi se, osim FSRU jedinice, među ostalim, obuhvatilo i brodove za prijevoz UPP-a, tegljače za manevriranje brodova tijekom dolaska, odnosno odlaska s terminala te protupožarni tegljač koji je u pripravnosti tijekom iskrcaja UPP-a.

18 Na temelju notifikacije o sukcesiji Republika Hrvatska stranka je navedene Konvencije od 8. listopada 1991., Narodne novine, Međunarodni ugovori, br. 1/1992, dalje u tekstu: SOLAS konvencija.

19 Resolution MSC. 5(48), usvojen uz SOLAS konvenciju, stupio na snagu 1. srpnja 1986. godine. Izmjene Kodeksa usvojene u Resolution MSC. 370(93) stupile su na snagu 1. siječnja 2016. godine, dalje u tekstu: Kodeks za prijevoz UPP-a.

20 Koska-Legieć, A., What is the Real Issue with Floating Storage and Regasification Units? Regulations Related to the FSRU Implementation Process in the Baltic Sea, TransNav, The International Journal on Marine Navigation and Safety of Sea Transportation, vol. 12, br. 3, 2018., str. $501-503$.

21 Narodne novine, Međunarodni ugovori, br. 10/2006, dalje u tekstu: AFS konvencija, stupila na snagu 17. rujna 2008. godine. 


\section{PROCJENA UTJECAJA NA OKOLIŠ}

Imajući u vidu prevenciju kao primarni cilj pri uređenju pitanja zaštite morskog okoliša i okoliša općenito, u međunarodnim ugovorima propisuje se obveza provođenja postupka procjene utjecaja određenih gospodarskih i sličnih djelatnosti na okoliš, i to prije nego što ih se poduzme. Taj postupak pruža potrebne stručne podatke o posljedicama koje bi planirane djelatnosti mogle imati na okoliš, kako osobama mjerodavnim za donošenje odluka o poduzimanju takvih djelatnosti, tako i onim osobama koje bi mogle biti pogođene posljedicama planiranih djelatnosti, pritom omogućujući da se i one uključe u proces donošenja odluka. ${ }^{22} \mathrm{Na}$ temelju prikupljenih podataka pristupa se utvrđivanju mjera potrebnih za sprječavanje i smanjivanje štetnih posljedica, odnosno provođenju programa praćenja stanja okoliša prije, tijekom i nakon poduzimanja planiranih djelatnosti.

Obveza procjene utjecaja na okoliš kodificirana je člankom 206. Konvencije iz 1982. kojim se propisuje da "kada države zbog ozbiljnijih razloga smatraju da planirane djelatnosti pod njihovom jurisdikcijom ili nadzorom mogu uzrokovati veliko onečišćenje ili znatne i štetne promjene u morskom okolišu, one procjenjuju, koliko god je to provedivo, moguće posljedice takvih djelatnosti na morski okoliš i izvještavaju o rezultatima takvih procjena...”. Za utvrđivanje postojanja obveze provođenja postupka procjene utjecaja određenih djelatnosti na okoliš valja utvrditi postojanje određenog stupnja vjerojatnosti i predvidljivosti nastupanja štetnih posljedica za okoliš, kao i njihovih razmjera. ${ }^{23}$ Primjerice, čl. 2. st. 1. Direktive 2011/92 Europskog parlamenta i Vijeća od 13. prosinca 2011. godine o procjeni učinaka određenih javnih i privatnih projekata na okoliš propisuje da države članice podvrgavaju procjeni utjecaja one projekte "koji bi mogli imati značajne učinke na okoliš, među ostalim na temelju njihove prirode, veličine ili lokacije".

Republika Hrvatska detaljnije je uredila postupak procjene utjecaja na okoliš nacionalnim propisima, u prvom redu Zakonom o zaštiti okoliša ${ }^{24}$ i Uredbom o procjeni utjecaja zahvata na okoliš ${ }^{25}$ kao podzakonskim aktom. Sukladno

22 Sands, P., Principles of international environmental law I: Frameworks, standards and implementation, Manchester University Press, Manchester - New York, 1995., str. 579.

23 Seršić, M., Međunarodnopravna zaštita morskog okoliša, Pravni fakultet Sveučilišta u Zagrebu, Zagreb, 2003., str. 30.

24 Narodne novine, br. 80/2013, 153/2013, 78/2015, 12/2018 i 118/2018, dalje u tekstu: ZZO.

25 Narodne novine, br. 61/2014 i 3/2017. 
odredbama navedenih propisa ${ }^{26}$ za građevine namijenjene skladištenju - naftni terminali i terminali ukapljenog prirodnog plina - propisana je obvezna procjena utjecaja zahvata na okoliš, pri čemu postupak provodi Ministarstvo zaštite okoliša i energetike (dalje u tekstu: Ministarstvo). Tako je od strane stručne pravne osobe $\mathrm{u}$ provedenom postupku u vezi s izgradnjom plutajućeg terminala na otoku Krku izrađena studija o utjecaju na okoliš (dalje u tekstu: Studija) ${ }^{27}$, koja predstavlja stručnu podlogu za odlučivanje o prihvatljivosti planirane djelatnosti za okoliš. Kratka analiza mjerodavnih poglavlja službene Studije, ne ulazeći u analizu drugih neovisnih studija, iznosi se u sljedećim odjeljcima.

\section{1. Štetni utjecaji na morski okoliš tijekom rada plutajućeg terminala}

Iako Studija obrađuje raznorodne štetne utjecaje koji se mogu pojaviti tijekom rada plutajućeg terminala, poput utjecaja buke i vibracije, utjecaja na strukturne i vizualne značajke krajobraza, utjecaja prometa, utjecaja na gospodarenje otpadom, na kulturnu baštinu, na klimatske promjene te utjecaj svjetlosnog onečišćenja, oni se ne analiziraju u ovome radu jer se ne odnose izravno na onečišćenje morskog okoliša, odnosno ako se i odnose, riječ je o utjecajima koji su unutar prihvatljivih granica ili su ponajprije prisutni u fazi gradnje terminala. Ono što se pak analizira su utjecaji djelatnosti hlađenja morske vode i ispuštanja štetnih tvari poput nusprodukata klora te bakra u more, koji su pretrpjeli najviše kritika u javnosti ${ }^{28}$, te utjecaj emisije dušikovih i sumpornih oksida u zrak.

\subsubsection{Utjecaj djelatnosti hlađenja morske vode te ispuštanja štetnih tvari u more}

Protivnici izgradnje plutajućeg terminala najviše kritiziraju upravo proces tijekom kojega bi se koristila toplina morske vode u svrhu grijanja plina na temperaturu plinovoda. U tom slučaju štetan utjecaj na more i morski okoliš najviše bi dolazio do izražaja u ožujku, kada je temperatura mora na lokaciji plutajućeg terminala najniža.

26 Čl. 76. - 94. ZZO-a i čl. 4. - 21. Uredbe o procjeni utjecaja zahvata na okoliš, a u vezi s točkom 42. Priloga I. Uredbe.

27 https://lng.hr/lib/plugins/kcfinder/upload/files/Studija\%20o\%20utjecaju\%20na\%20 okoli\%C5\%Al\%20za\%20plutaju\%C4\%87i\%20terminal\%20za\%20ukapljeni\%20 prirodni\%20plin.pdf (1. kolovoza 2019.).

28 https://radio.hrt.hr/radio-rijeka/clanak/eko-kvarner-replinifikacija-pomocu-mora-i-klora-iznimno-stetna-za-okolis/165731/ (1. kolovoza 2019.). 
Ipak, s obzirom na postojeće slobodne morske struje i okolnosti raspada morskog mlaza na predmetnoj lokaciji, zaključak je Studije da najveća razlika u temperaturi mora ne bi prešla I Celzijev stupanj te da kao takva ne bi bila od znatnog utjecaja na život u moru u smislu da ne bi dovela u pitanje biološku raznolikost predmetnog područja.

Nadalje, sporan je i utjecaj kloriranja morske vode u svrhu sprječavanja stvaranja obraštaja. ${ }^{29}$ Iako se tvrdi da se neće koristiti sustav elektroklorinacije, kojim se putem elektrolize iz morske soli (natrijeva klorida) proizvodi otopina natrijevog hipoklorita, ipak je potrebno osvrnuti se na njega već zbog same činjenice da navedeni sustav postoji na FSRU jedinici. S jedne strane, u odnosu na utjecaj na ribe, problematično je stvaranje nusprodukata kloriranja koji nastaju u reakcijama između klora i mineralnih i organskih sastojaka prirodnih voda. S druge strane, sam način funkcioniranja sustava elektroklorinacije izaziva štetan utjecaj na morske ekosustave koji bi se očitovao u tome što bi u sustav isparivača bili uvučeni svi planktonski organizmi manji od dimenzija rešetke postavljene na usisu vode pa bi ti organizmi onda i uginuli.

U odnosu na izložene rizike, zaključak Studije je da, zbog manje biološke produktivnosti mora na tom području, tj. rjeđe pojave obraštaja ${ }^{30}$, neće ni biti potrebe za kloriranjem, a ako ono ipak bude potrebno, provest će se u manjem opsegu, i to najvećim dopuštenim ispuštanjem ukupnih ostatnih oksidanata do $0,1 \mathrm{mg} / \mathrm{l} \mathrm{s}$ obzirom da izloženost riba tako niskim razinama ne pridonosi stvaranju ekotoksikološkog stresa.

U vezi s time valjalo bi utvrditi koji bi sve nusprodukti klora mogli biti ispušteni u radu plutajućeg terminala te ako se utvrdi da nema osnove za zabranu uporabe klora, onda bi predmetno ispuštanje valjalo podvrgnuti izdavanju posebne dozvole sukladno propisanoj najvećoj dopuštenoj koncentraciji nusprodukata klora u moru.

$\mathrm{Na}$ kraju, sporno je i korištenje premaza na bazi bakra za sprječavanje stvaranja obraštaja na trupu broda. Iako je na svjetskoj razini usvojena AFS Konvencija te na regionalnoj razini Uredba 528/2012 Europskog parlamenta

29 Definiciju obraštaja vidi u Pomorska enciklopedija, sv. 5., Mito-Pa, Jugoslavenski leksikografski zavod "Miroslav Krleža”, Zagreb, 1981., str. 502: “Obraštanje brodskog trupa morskim biljkama i životinjama odavna je bio i ekonomski problem ... brodarska poduzeća snose znatne troškove zbog te pojave. Utjecaj hrapave površine uronjenog trupa na otpor trenja uočen je i potvrđen ispitivanjima mnogih autora...".

30 Ipak, o pozitivnom utjecaju proizvodnih platformi na nastanak i razvoj obraštaja na Jadranu u istraživanju provedenom od 2002. do 2015. godine vidi Bakran-Petricioli, T.; Smital, T.; Petricioli, D.; Mlinarić, D., Obraštaj na plinskim platformama u Jadranu kao pokazatelj stanja okoliša, Nafta i plin, vol. 35, br. 42, 2015., str. $79-80$. 
i Vijeća od 22. svibnja 2012. godine o stavljanju na raspolaganje na tržištu i uporabi biocidnih proizvoda, najveća dopuštena koncentracija bakra u moru je uređena tek na nacionalnoj razini, i to Uredbom o standardu kakvoće voda. ${ }^{31}$ U slučaju korištenja protuobraštajnih boja, sukladno procjeni Studije, koncentracija bakra u vodi bila bi unutar dopuštenih ograničenja te, stoga, ne bi bilo znatnih štetnih utjecaja na morski okoliš.

\subsubsection{Utjecaj emisije dušikovih i sumpornih oksida}

Iako po svom razmjeru nisu štetni kao prethodno navedeni utjecaji, valja spomenuti i onečišćenje zraka uslijed emisija dušikovih i sumpornih oksida tijekom rada plutajućeg terminala, koje može posredno uzrokovati i onečišćenje morskog okoliša. U čl. 212. st. 3. Konvencije iz 1982. navodi se da države "donose zakone i druge propise, te poduzimaju druge mjere potrebne za izvršavanje primjenjivih međunarodnih pravila i standarda ... radi sprječavanja, smanjivanja i nadziranja onečišćenja morskog okoliša iz zraka ili putem zraka...". U skladu s time, Republika Hrvatska donijela je niz zakonskih i podzakonskih akata u svrhu prevencije onečišćenja. ${ }^{32}$ Mjere zaštite određene tim propisima poduzimaju se u cilju izvršenja obveza preuzetih međunarodnim ugovorima. ${ }^{33}$ Među njima je, osim Konvencije iz 1982., u svakom slučaju i MARPOL konvencija, odnosno njezin Prilog VI: Pravila o sprječavanju onečišćenja zraka s brodova iz 1997. godine, koji je na snazi izmijenjen Rezolucijom iz 2008. godine. ${ }^{34}$

Sukladno procjeni iz Studije, najznačajniji utjecaj rada plutajućeg terminala na morski okoliš može biti u pogledu emisije dušikovih oksida, a znatno manji u pogledu emisije sumpornih oksida i čestica. U odnosu na dušikove okside, pravilo 13, t. 3.a. Priloga VI propisuje ograničenja njihova ispuštanja iz dizelskog

31 Narodne novine, br. 96/2019.

32 Primjerice, Zakon o zaštiti zraka (Narodne novine, br. 127/2019), Uredba o kvaliteti tekućih naftnih goriva i načinu praćenja i izvješćivanja te metodologiji izračuna emisija stakleničkih plinova u životnom vijeku isporučenih goriva i energije (Narodne novine, br. 57/2017, dalje u tekstu: Uredba o kvaliteti tekućih naftnih goriva), Pravilnik o praćenju kvalitete zraka (Narodne novine, br. 79/2017).

33 Pritom je Republika Hrvatska, kao obalna država, ovlaštena donositi zakone i druge propise koji mogu biti i stroži i blaži od međunarodnih pravila, s obzirom na to da na temelju čl. 212. st. 1. Konvencije iz 1982. treba samo “...voditi računa o međunarodno priznatim pravilima, standardima, te preporučenoj praksi i postupcima, kao i o sigurnosti zračne plovidbe".

34 Resolution MEPC. 176(58), stupio na snagu 1. srpnja 2010. godine, dalje u tekstu: Prilog VI. 
motora, koja ovise o brzini vrtnje motora, dok pravilo $14 \mathrm{u}$ odnosu na sumporne okside uređuje dopuštene emisije kroz kvalitetu goriva.

Kao jedan od izvora emisija u zrak, FSRU jedinica koristit će prirodni plin kao gorivo, kako u motorima, tako i u parnim kotlovima, pa će u pogledu štetnih utjecaja na zrak najznačajnije biti emisije dušikovih oksida. Nadalje, brodovi za prijevoz UPP-a, kao povremeni izvor emisija u zrak, koristit će prirodni plin i/ili tekuće brodsko gorivo, a štetni utjecaj tih brodova ovisit će, osim o vrsti goriva, i o tipu postrojenja (parna turbina ili dizelski motor) koji koriste. Također, izvori emisija u zrak su i tegljači za manevriranje brodova tijekom dolaska, odnosno odlaska s terminala te protupožarni tegljač koji je u pripravnosti tijekom iskrcaja UPP-a.

Slijedom naprijed navedenog, Prilog VI postavlja pravilo u pogledu obveze podvrgavanja pregledu motora i opreme brodova ${ }^{35}$, a zatim, nakon obavljenog pregleda, propisuje izdavanje ili potvrđivanje međunarodne svjedodžbe o sprječavanju onečišćenja zraka. ${ }^{36}$ Osim toga, daju se određene ovlasti državi luke u pogledu provedbe nadzora nad radnim postupcima na brodu “... ako postoji osnovana sumnja da zapovjednik broda ili posada nisu dobro upoznati s bitnim postupcima na brodu koji se odnose na sprječavanje onečišćenja zraka s brodova". 37

Navedene ovlasti proizlaze već iz same suverenosti koju Republika Hrvatska uživa u svojim unutrašnjim morskim vodama u kojima se nalazi plutajući terminal. Naime, Republika Hrvatska je nadležna provoditi građansku i kaznenu sudbenost nad brodovima za prijevoz UPP-a i posadom za djela počinjena za vrijeme njihova boravka pri terminalu, ali i prije ulaska u unutrašnje morske vode, i to u morskim prostorima nad kojima uživa suverenost ili suverena prava. ${ }^{38}$ Dakle, pravni položaj stranih brodova za prijevoz UPP-a kada se nalaze uz plutajući terminal jednak je položaju stranih trgovačkih brodova u lukama otvorenima za međunarodni promet, kako u smislu prava na pristup plutajućem terminalu, tako i u smislu obveze podvrgavanja sudbenosti Republike Hrvatske u naprijed opisanim slučajevima.

35 Pravilo 5. Priloga VI.

36 Pravila od 6. do 9. Priloga VI.

37 Pravila od 10. do 11. Priloga VI.

38 Degan, V. Đ., Internal waters, Netherlands Yearbook of International Law, vol. 17, 1986., str. 26. Za potrebe ovog rada pod terminom "terminal" misli se na termin "luka" iz naprijed navedenog članka s obzirom na to da je riječ o FSRU jedinici koja je usidrena kraj luke (op. a). 


\subsection{Mjere zaštite morskog okoliša}

Nakon održane javne rasprave o objavljenoj Studiji ${ }^{39}$ Ministarstvo je Rješenjem ${ }^{40}$ utvrdilo da je planirani zahvat prihvatljiv za okoliš uz primjenu mjera zaštite okoliša i provedbu programa praćenja stanja okoliša.

\subsubsection{Mjere zaštite mora}

Tako se u Rješenju Ministarstva, u odnosu na zaštitu voda među ostalim navodi da je potrebno stalno pratiti temperaturu morske vode na usisu i na ispustu sustava rashladne vode i sustava isparivača te mjeriti koncentracije klora, nusprodukata kloriranja i bakra u morskoj vodi. U odnosu na kloriranje, najveće dopušteno ispuštanje ukupnih ostatnih oksidanata može biti do $0,1 \mathrm{mg} / \mathrm{l}$. U odnosu na ispuštanje bakra, nije dopušteno čišćenje trupa broda protuobraštajnim bojama, osim čišćenja rešetki na području zahvata vode.

\subsubsection{Miere zaštite zraka}

Emisije dušikovih oksida moraju zadovoljiti granične vrijednosti iz Priloga VI MARPOL konvencije, a emisije sumpornih oksida iz brodskog dizelskog goriva UPP brodova tijekom boravka broda na vezu, uključujući i istovar UPP-a, mogu biti najviše do $0,1 \% \mathrm{~m} / \mathrm{m} .{ }^{41}$ Također, u okviru programa praćenja stanja okoliša tijekom rada terminala potrebno je na mjernoj postaji stalno pratiti satne koncentracije dušikovih i sumpornih oksida na području naselja Omišalj te, sukladno Uredbi 601/2012 od 21. lipnja 2012. godine o praćenju i izvješćivanju o emisijama stakleničkih plinova u skladu s Direktivom 2003/87/EZ Europskog parlamenta i Vijeća, Ministarstvu dostavljati izvješća o poboljšanjima metodologije praćenja.

39 Sažetak primjedbi iznesenih u javnoj raspravi vidi u: Rješenje Ministarstva, KLASA: UP/I-351-03/17-02/74, URBROJ: 517-06-2-1-1-18-6 od 11. travnja 2018. godine, str. $14-15$.

40 Ibid.

${ }^{41}$ Čl. 13. st. 5. Uredbe o kvaliteti tekućih naftnih goriva. Time je Republika Hrvatska propisala stroži standard u odnosu na Prilog VI koji, sukladno izmjenama sa 70. sjednice MEPC-a iz 2016. godine, koje su stupile na snagu 1. siječnja 2020. godine, ograničuje sadržaj sumpora u brodskom gorivu na $0,5 \% \mathrm{~m} / \mathrm{m}$. 


\section{SPRJEČAVANJE ONEČIŠĆENJA MORSKOG OKOLIŠA (PREVENCIJA)}

Na temelju naprijed izloženih opasnosti i štetnih utjecaja na morski okoliš, koji se mogu pojaviti tijekom rada plutajućeg terminala, postavlja se načelo prevencije, koje je načelo općeg običajnog međunarodnog prava i jedno od temeljnih načela zaštite i očuvanja okoliša ${ }^{42}$ kao prvi korak u zaštiti morskog okoliša. Ono postavlja obvezu državama da poduzmu potrebne mjere kako bi spriječile da do onečišćenja morskog okoliša uopće dođe. Pritom prilikom ocjene o tome je li država poduzela sve odgovarajuće mjere, odnosno prilikom utvrđivanja moguće međunarodne odgovornosti države za kršenje obveze prevencije, prevladava standard dužne pažnje ${ }^{43}$, koji se može definirati, primjerice, na način opisan člankom 194. st. l. Konvencije iz 1982. u kojem se navodi da "države, pojedinačno ili zajednički, prema prilikama, poduzimaju sve mjere u skladu s ovom Konvencijom koje su potrebne da bi se spriječilo, smanjilo i nadziralo onečišćenje morskog okoliša iz bilo kojeg izvora, koristeći u tu svrhu najprikladnija sredstva kojima raspolažu, a u skladu sa svojim mogućnostima, te nastoje uskladiti svoje politike s tim u vezi”. Dakle, država je dužna poduzeti sve potrebne mjere, a ako i unatoč tome nastupe štetne posljedice, država neće biti međunarodno odgovorna ako je, uzimajući u obzir okolnosti svakog pojedinog slučaja, poduzela sve u svojim mogućnostima da spriječi onečišćenje i štetu.

Republika Hrvatska je, u skladu s preuzetim međunarodnim obvezama, dužna poduzeti odgovarajuće mjere kako bi se spriječile štetne posljedice djelatnosti plutajućeg terminala na morski okoliš i okoliš općenito. Iako su uglavnom usvojeni odgovarajući nacionalni propisi, neka je područja još potrebno urediti, primjerice podvrgnuti ispuštanje određenih kemikalija proizašlih iz djelatnosti plutajućeg terminala izdavanju posebnih dozvola. ${ }^{44}$ Stoga, preostaje pratiti usklađenost nacionalnih propisa s međunarodnim pravilima i samu provedbu tih propisa tijekom rada plutajućeg terminala.

42 O ostalim temeljnim načelima zaštite i očuvanja okoliša vidi Sands, op. cit. u bilj. 22 , str. $183-220$.

43 Shaw, M. N., International Law, 4. izdanje, Cambridge University Press, Cambridge, 1997., str. $592-594$.

44 Vidi supra 4.1.1. 


\subsection{Prilog II uz MARPOL konvenciju: Pravila o sprječavanju onečišćenja štetnim tekućim tvarima}

Međunarodno pravo prepoznalo je onečišćenje s brodova kao zaseban izvor onečišćenja morskog okoliša ${ }^{45}$, pri čemu, u kontekstu predmeta ovoga rada, valja razmotriti onečišćenje s brodova koji prevoze UPP upravo zbog naprijed opisanih opasnosti koje mogu nastati uslijed isparavanja plina. ${ }^{46} \mathrm{U}$ tom pogledu Republika Hrvatska usvojila je Prilog II uz MARPOL konvenciju: Pravila o sprječavanju onečišćenja štetnim tekućim tvarima koje se prevoze u trupu ${ }^{47}$, kao i odgovarajuće nacionalne propise, primjerice, Pravila za statutarnu certifikaciju pomorskih brodova, Sprječavanje onečišćenja ${ }^{48}$, čije su odredbe u skladu s Prilogom II.

Metode kojima se nastoji spriječiti onečišćenje odnose se na usvajanje odgovarajućih odredbi o konstrukciji i opremi brodova te o obučenosti posade u pogledu rukovanja teretom. Tako Prilog II, između ostalog u Pravilu V, st. 3. propisuje dodatne zahtjeve za konstrukciju i opremu brodova za prijevoz ukapljenih plinova kao što su posjedovanje Svjedodžbe o prikladnosti, u skladu s odgovarajućim Kodeksom za prijevoz UPP-a za brodove kojima je dopušten prijevoz ukapljenih plinova u trupu; posjedovanje Međunarodne svjedodžbe o sprječavanju onečišćenja pri prijevozu štetnih tekućih tvari u trupu, u kojoj je potvrđeno da brod za prijevoz plina može prevoziti samo one štetne tekuće tvari utvrđene i navedene u odgovarajućem Kodeksu za prijevoz UPP-a (pri čemu valja naglasiti da je svjedodžba koju je izdala jedna ugovorna strana valjana i na području druge ugovorne strane); zatim zahtjev u pogledu opremljenosti uređajima za odvojeni balast; kao i sustavom crpki i cjevovoda te na kraju posjedovanje Priručnika o postupcima i mjerama koji osigurava da neće doći do nikakvog miješanja ostataka tereta i vode tijekom rada i da se nikakvi ostaci neće zadržati u tanku nakon što su primijenjeni postupci ventilacije propisani Priručnikom. Nadalje, Pravilo 17 Priloga II propisuje za svaki brod od 150 bruto tonaže i veći koji smije prevoziti štetne tekuće tvari u trupu obvezu posjedovanja brodskog plana sprječavanja onečišćenja mora štetnim tekućim tvarima u nuždi, čiji je minimalni sadržaj propisan istim Pravilom.

45 Konvencija iz 1982. u čl. 207. - 212. nabraja i ostale izvore onečišćenja mora: iz izvora na kopnu, od djelatnosti na morskom dnu podložnih nacionalnoj jurisdikciji, od djelatnosti u Zoni, potapanjem, iz zraka ili putem zraka.

\section{Prilog II. Ugovorne stranke MARPOL konvencije obvezne su primjenjivati prva dva} od šest priloga. 
Već je iz izloženih odredbi Priloga II vidljivo da MARPOL konvencija predstavlja temeljni međunarodni ugovor za zaštitu morskog okoliša od onečišćenja s brodova, postavljajući čvrsta pravila usmjerena na prevenciju onečišćenja. Riječ je o međunarodnom ugovoru koji se neprestano mijenja i dopunjuje, unoseći tako u svoj sadržaj najnovije rezultate znanstvenih istraživanja o morskom okolišu, odnosno pravno razrađena rješenja potaknuta novonastalim problemima onečišćenja morskog okoliša u svijetu, čime daje poticaj i nacionalnim zakonodavstvima za usvajanjem odgovarajućih izmjena i dopuna.

\section{SMANJIVANJE I NADZIRANJE ONEČIŠĆENJA MORSKOG OKOLIŠA (INTERVENCIJA)}

Ako unatoč poduzetim preventivnim mjerama ipak nije moguće spriječiti onečišćenje morskog okoliša, države su dužne surađivati u smanjivanju i nadziranju onečišćenja, i to sukladno planovima hitnih mjera. Navedeno proizlazi već iz Konvencije iz 1982. koja u čl. 197. propisuje da "radi zaštite i očuvanja morskog okoliša države surađuju na svjetskoj razini i, ako je potrebno, na regionalnoj, izravno ili preko nadležnih međunarodnih organizacija, u sastavljanju i razradi međunarodnih pravila, standarda te preporučene prakse i postupaka u skladu s ovom Konvencijom, vodeći računa o regionalnim osobitostima”. U tu svrhu države moraju zajednički donositi i promicati planove hitnih mjera za djelovanje u slučajevima nezgoda koje dovode do onečišćenja morskog okoliša te razmjenjivati informacije i podatke o onečišćenju morskog okoliša. ${ }^{49}$

Međunarodni ugovor koji na svjetskoj razini uređuje pitanje djelovanja u skladu s planom za akciju za slučaj onečišćenja je Međunarodna konvencija o pripravnosti, akciji i suradnji za slučaj onečišćenja uljem iz 1990. godine. ${ }^{50}$ Budući da je ona primjenjiva samo na nezgode onečišćenja uljem ${ }^{51}$, područje njezine primjene prošireno je Protokolom o pripravnosti, odgovoru i suradnji kod onečišćenja mora opasnim i štetnim tvarima iz 2000. godine ${ }^{52}$ koji se, dakle, primjenjuje na onečišćenje koje potječe od događaja ili niza događaja istog

49 Čl. 198. - 200. Konvencije iz 1982.

50 Narodne novine, Međunarodni ugovori, br. 2/1997, stupila na snagu u Republici Hrvatskoj 12. travnja 1998. godine, dalje u tekstu: OPRC konvencija.

${ }^{51}$ Čl. 2. st. 1. OPRC konvencije navodi da ulje označuje naftu u bilo kojem obliku, uključujući sirovu naftu, gorivo, kaljužu, uljni otpad i derivate.

52 https://www.ecolex.org/details/treaty/protocol-on-preparedness-response-and-co-operation-to-pollution-incidents-by-hazardous-and-noxious-substances-tre-002482/? Dalje u tekstu: HNS Protokol. 
podrijetla, uključujući požar ili eksploziju, koji rezultiraju ili mogu rezultirati ispuštanjem opasnih i štetnih tvari ${ }^{53}$ koje predstavljaju ili mogu predstavljati prijetnju morskom okolišu, obali ili povezanim interesima jedne ili više država, a koje zahtijevaju hitno djelovanje ili hitan odgovor. Odredbe HNS Protokola uglavnom se odnose na dužnost države da zahtijeva od odgovornih osoba da imaju planove za akciju te da se pridržavaju postupaka izvještavanja o nezgodama, zatim dužnost ustanovljavanja nacionalnih sustava za pripravnost i odgovor te suradnju u razmjeni rezultata istraživanja o provedbi pripravnosti i odgovora kod onečišćenja.

Republika Hrvatska nije obvezna primjenjivati HNS Protokol s obzirom na to da za nju nije na snazi, već jedino OPRC konvenciju, no, sukladno naprijed navedenom, ona nije primjenjiva na slučajeve onečišćenja koji bi mogli biti uzrokovani djelatnostima plutajućeg terminala. Ipak, može se reći da neprimjenom HNS Protokola Jadransko more nije na gubitku jer je suzbijanju onečišćenja u tom području pristupljeno učinkovitim regionalnim te daljnjim nacionalnim uređenjem kako slijedi u nastavku.

\subsection{Barcelonska konvencija i Protokol iz 2002. godine}

Republika Hrvatska, kao i ostale države na obali Jadranskog mora, stranka je Konvencije o zaštiti morskog okoliša i obalnog područja Sredozemlja iz 1976., izmijenjene 1995. godine ${ }^{54}$, koja predstavlja regionalni pristup uređenju zaštite Sredozemnog mora te postavlja pravni okvir s općom obvezom njegove zaštite od svih izvora onečišćenja, dok svojim dodatnim Protokolima razrađuje detaljnije obveze za stranke Konvencije. Upravo ta opća obveza zaštite izmijenjena je 1995. godine pod utjecajem proboja načela održivog razvitka nakon održane Konferencije Ujedinjenih naroda o okolišu i razvitku u Rio de Janeiru 1992. godine. Tako dopunjeni čl. 4. Barcelonske konvencije propisuje da će ugovorne stranke "pojedinačno ili zajednički poduzimati sve odgovarajuće mjere ... kako

53 Čl. 2. st. 2. HNS Protokola navodi da je opasna i štetna tvar svaka druga tvar osim nafte koja, ako se unese u morski okoliš, može uzrokovati opasnost za ljudsko zdravlje, štetu živim prirodnim bogatstvima i životu u moru, štetu imovini ili ometati druge zakonite uporabe mora.

54 Na temelju notifikacije o sukcesiji Republika Hrvatska stranka je navedene Konvencije od 8. listopada 1991. (Narodne novine, Međunarodni ugovori, br. 12/1993). Izvorni tekst na engleskom jeziku vidljiv je na poveznici http://wedocs.unep.org/ bitstream/id/53143/convention_eng.pdf. Izmjene Konvencije stupile su na snagu u odnosu na Republiku Hrvatsku 9. srpnja 2004. godine (Narodne novine, Međunarodni ugovori, br. 17/1998). Dalje u tekstu: Barcelonska konvencija. 
bi spriječile, suzbile, ublažile te u najvećoj mogućoj mjeri uklonile onečišćenje iz područja Sredozemnoga mora te štitile i unaprijedile morski okoliš u tom području tako da pridonesu njegovu održivom razvoju". Načelo održivog razvitka, premda nije običajnopravnog karaktera, sigurno utječe na oblikovanje nacionalnih i svjetskih politika zaštite okoliša jer, bez obzira na važnost gospodarskog razvoja, valja imati na umu i očuvanje okoliša te uravnotežiti ta dva suprotstavljena interesa. U ostvarivanju tog cilja Barcelonska konvencija propisuje da se ugovorne stranke moraju rukovoditi određenim načelima i metodama pa tako u čl. 4. st. 3. (c) i (d) te st. 4. među metodama koje se trebaju primijeniti navodi procjenu utjecaja na okolišs, usvajanje programa i mjera koji sadržavaju rokove za njihovu provedbu te upotrebu i prijenos tehnologije i prakse koji su najpovoljniji za okoliš.

Osim što je stranka Barcelonske konvencije, Republika Hrvatska stranka je i njezina Protokola o suradnji u sprječavanju onečišćavanja s brodova i, u slučajevima opasnosti, u suzbijanju onečišćavanja Sredozemnog mora iz 2002. godine..$^{55}$ Među njegovim značajnijim odredbama valja izdvojiti one o održavanju i unapređenju planova intervencija za slučaj iznenadnih onečišćenja, razvijanju i obavljanju aktivnosti monitoringa, obvezi međusobnog širenja i razmjene informacija o onečišćenju morskog okoliša te o poduzimanju svih mogućih operativnih mjera u cilju sprječavanja, smanjenja i otklanjanja štetnih posljedica onečišćenja. U tom smislu, u kontekstu predmeta ovog rada, država mora zahtijevati od osoba koje zapovijedaju postrojenjima na moru koja su pod njezinom jurisdikcijom da je izvješćuju o svim nezgodama koje su dovele ili mogu dovesti do ispuštanja (nafte ili) opasnih i štetnih tvari. Osim toga, država mora zahtijevati od operatera odgovornih za postrojenja na moru pod njezinom jurisdikcijom da imaju plan intervencija za slučaj iznenadnog onečišćenja.

Dakle, Protokol iz 2002. godine uređuje konkretne obveze ugovornih stranaka dok Barcelonska konvencija predstavlja okvirnu konvenciju s općim načelima i obvezama ugovornih stranaka. Osim toga, Protokolom iz 2002. godine ujedno je propisano da države mogu usvajati i strože domaće mjere u pogledu pitanja uređenih samim Protokolom. Tako je Republika Hrvatska usvojila nacionalni propis s još detaljnijim odredbama koje se izlažu u nastavku.

55 Narodne novine, Međunarodni ugovori, br. 12/2003, stupio na snagu u odnosu na Republiku Hrvatsku 17. ožujka 2004. godine. Dalje u tekstu: Protokol iz 2002. godine. 


\subsection{Plan intervencija kod iznenadnih onečišćenja mora}

Plan intervencija kod iznenadnih onečišćenja mora ${ }^{56}$ nacionalni je propis koji se primjenjuje u Republici Hrvatskoj u slučaju iznenadnog onečišćenja mora uljem i/ili smjesom ulja razmjera većeg od $2000 \mathrm{~m}^{3}$, opasnim i štetnim tvarima, te kod izvanrednih prirodnih događaja u moru (čl. 1. st. 3.), dok se za onečišćenja uljem i/ili smjesom ulja razmjera manjeg od $2000 \mathrm{~m}^{3}$, za manji opseg i jačinu izvanrednog prirodnog događaja u moru primjenjuje županijski plan intervencija. ${ }^{57}$

U cilju smanjivanja i uklanjanja opasnosti od onečišćenja mora propisane su mjere kao što su stavljanje u stanje pripravnosti tegljača, brodova čistača, civilne zaštite, službe za vatrogastvo, hitne medicinske pomoći, Gorske službe spašavanja te drugih mjera primjerenih zamijećenoj opasnosti od onečišćenja. U slučaju izvanrednog onečišćenja mora provode se mjere radi osiguranja onečišćenog područja od neovlaštenog pristupa i djelovanja, osiguranja nesmetanog uzorkovanja morske vode i po potrebi praćenja kakvoće zraka, zabrane izlova ribe u onečišćenom području i zabrane plovidbe onečišćenim područjem. Planom intervencija propisana je i obveza naknade troškova nastalih onečišćenjem morskog okoliša, pri čemu se zahtjev za naknadu štete podnosi protiv vlasnika broda, sukladno načelu "onečišćivač plaća". ${ }^{58}$

Slijedom svega navedenog, Plan intervencija, bez obzira na to što možda ne omogućuje predviđanje svih pojedinosti koje se mogu javiti vezano uz potrebu intervencije, ipak predstavlja pouzdan sustav pravila koji doprinosi smanjenju onečišćenja morskog okoliša te osigurava pravo na naknadu nastalih troškova. Usvajanjem Plana intervencija Republika Hrvatska ispunila je svoju međunarodno preuzetu obvezu te postavila pravnu osnovu za uređenje spremnosti i reagiranja na iznenadna onečišćenja mora i na izvanredne prirodne događaje u moru.

56 Narodne novine, br. 92/2008, dalje u tekstu: Plan intervencija.

57 Sukladno čl. 1. st. 4. Plana intervencija. U tom slučaju za područje rada plutajućeg terminala bio bi primjenjiv Plan intervencija kod iznenadnih onečišcenja mora u Primorsko-goranskoj županiji, donesen na 3. sjednici Županijske skupštine 15. srpnja 2009. godine (Službene novine, br. 26/2009 i 42/2012).

Sands, op. cit. u bilj. 22, str. $213-214$. 


\section{ODGOVORNOST ZA ONEČIŠĆENJE MORSKOG OKOLIŠA}

Sukladno općem načelu prava, poznatom i u građanskom pravu, i u međunarodnom pravu, svako protupravno djelo povlači odgovornost te dužnost popravljanja nastale štete.

U slučaju nastanka štetnih posljedica za morski okoliš pitanje odgovornosti za štetu postavlja se na razini odgovornosti države te na razini građanskopravne odgovornosti.

Odgovornost države postoji u slučaju nastupanja onečišćenja od djelatnosti pod njezinom jurisdikcijom ili kontrolom ako je tako nastala šteta uzrokovana činom ili propustom koji nije u skladu s međunarodnom obvezom države, a niže se navodi i pravni temelj odgovornosti države u slučaju izostanka protupravnosti. S druge strane, građanskopravnu odgovornost, koja je obično strože naravi, snosi fizička ili pravna osoba koja se bavi djelatnošću koja je uzrokovala štetu te se obično propisuje nacionalnim zakonodavstvom, ali i međunarodnim ugovorima.

\subsection{Odgovornost države}

Komisija za međunarodno pravo u svojem je Nacrtu pravila o odgovornosti država uredila elemente međunarodno protupravnoga djela države. Tako se u članku 2. Nacrta navode dva elementa: pripisivost državi takvog protupravnog ponašanja, bilo činjenja ili nečinjenja, na temelju međunarodnog prava (subjektivni element) te, kumulativno, povreda međunarodne obveze države (objektivni element).

U slučaju da u radu plutajućeg terminala dođe do onečišćenja morskog okoliša uslijed propuštanja Republike Hrvatske da poduzme sve potrebne mjere u svrhu sprječavanja štete od onečišćenja, država bi odgovarala za povredu međunarodne obveze i bila bi obvezna naknaditi štetu. Ipak, ako bi država pritom postupala u skladu sa standardom dužnje pažnje ${ }^{59}$, ne bi bila međunarodnopravno odgovorna. Međutim, uzimajući u obzir da kada bi šteta u tom slučaju nastala, i to bez obzira što bi bila uzrokovana djelatnošću koja nije protupravna, valjalo bi u interesu oštećenika osigurati pravo na naknadu štete. Stoga se u sljedećem odjeljku analizira pravna osnova obveze na naknadu štete u slučaju kada nije došlo do povrede međunarodne obveze.

59 Vidi supra 5. 


\subsubsection{Odgovornost bez protupravnosti}

Premda bi se djelatnošću terminala za UPP mogle ostvariti opisane koristi ${ }^{60}$, valja imati na umu da takve djelatnosti povlače i rizik od nastupanja štetnih posljedica, i to takvih posljedica koje se ni uz najveću pažnju nekada jednostavno ne mogu izbjeći. U međunarodnom pravu takve djelatnosti poznate su pod pojmom djelatnosti s povećanom opasnošću. U Nacrtu članaka o međunarodnoj odgovornosti za štetne posljedice koje proizlaze iz čina koji nisu zabranjeni međunarodnim pravom definirane su kao djelatnosti koje uključuju rizik od uzrokovanja značajne štete. ${ }^{61}$ To su djelatnosti koje su dopuštene međunarodnim pravom, poput djelatnosti miroljubive upotrebe nuklearne energije, prijevoza nafte morem ili u ovom slučaju prijevoza, skladištenja i uplinjavanja ukapljenog prirodnog plina, ali koje, bez obzira na to što nisu protupravne, odnosno nisu protivne međunarodnoj obvezi, mogu proizvesti značajnu štetu. Tako, primjerice, u radu plutajućeg terminala, uslijed nepovoljnog omjera kisika i plina, može doći do nekontrolirane eksplozije ili požara pa se otvara i pitanje odgovornosti za štetu uzrokovanu djelatnostima s povećanom opasnošću.

Sukladno sustavu odgovornosti bez protupravnosti, država bi, nakon utvrđenja uzročne veze između djelatnosti i štete, odgovarala za štetne posljedice djelatnosti pod svojom kontrolom ili jurisdikcijom, bez obzira na to što takve djelatnosti nisu protupravne, tim više što neka djelatnost danas može biti zabranjena, a sutra dopuštena. ${ }^{62}$

Komisija za međunarodno pravo bezuspješno je pokušala urediti pitanje odgovornosti države za radnje koje nisu zabranjene međunarodnim pravom, zbog čega M. Seršić njezin rad naziva "regresivnim razvitkom državne prakse"63 jer umjesto da usvoji pravila o odgovornosti države koja bi mogla predstavljati pravni temelj za obvezu naknade štete od strane države, zapravo je samo istaknula dužnost države da osigura odgovornost privatnih osoba koje se bave opasnim djelatnostima. Naime, sukladno višedesetljetnoj praksi, države nisu bile sklone preuzeti odgovornost na sebe u takvom slučaju pa su je prebacile na privatne

60 Vidi supra 1.

61 United Nations, International Law Commission, Report on the work of its fifty-eight session (1 May - 9 June and 3 July - 11 August 2006), A/61/10, str. 58.

62 Sucharitkul, S., State Responsibility and International Liability under International Law, Loyola of Los Angeles, International and Comparative Law Journal, vol. 18, br. 4, 1996., str. 833 - 834.

63 Seršić, M., Odgovornost za onečišćenje morskog okoliša: međunarodnopravna odgovornost država i građanskopravna odgovornost, Zbornik Pravnog fakulteta u Zagrebu, vol. 58, br. 1-2, 2008., str. 269 - 274. 
osobe te su, osim nacionalnih zakona, donijele i međunarodne ugovore koji je detaljno uređuju, pri čemu su se kao najučinkovitije ${ }^{64}$ pokazale Međunarodna konvencija o građanskoj odgovornosti za štetu zbog onečišćenja uljem iz 1969. godine, izmijenjena Protokolom iz 1992. godine, i prateća Međunarodna konvencija o osnivanju Međunarodnog fonda za naknadu štete zbog onečišćenja uljem iz 1971., izmijenjena Protokolom iz 1992. godine. ${ }^{65}$

Prema sadašnjem stupnju razvoja međunarodnog prava država bi mogla snositi odgovornost bez obzira na nepostojanje protupravnosti jedino u slučaju izričitog ugovaranja takve odgovornosti. Stoga preostaje pričekati i analizirati sadržaj ugovora koji se tek treba sklopiti s poduzetnikom kojemu će se terminal predati u zakup. ${ }^{66}$

\subsection{Građanskopravna odgovornost}

Budući da se odredbe PZ-a o izvanugovornoj odgovornosti za štetu koja nastane osobama, stvarima izvan broda te okolišu primjenjuju na plovne objekte ${ }^{67}$, za štetu od onečišćenja morskog okoliša uzrokovanu djelatnostima s plutajućeg terminala (koji nema status plovnog objekta ${ }^{68}$ ), odgovara se na temelju općih propisa obveznog prava, odnosno Zakona o obveznim odnosima. ${ }^{69}$ Pritom je, s jedne strane, moguća primjena pravila o subjektivnoj odgovornosti koja pred-

64 Ćorić, D., Međunarodnopravni sustav odgovornosti i naknade štete zbog onečišćenja mora uljem, Hrvatska akademija znanosti i umjetnosti, Jadranski zavod, Zagreb, 2002., str. 212.

65 Na temelju notifikacije o sukcesiji Republika Hrvatska stranka je Međunarodne konvencije o građanskoj odgovornosti za štetu zbog onečišćenja uljem i Međunarodne konvencije o osnivanju Međunarodnog fonda za naknadu štete zbog onečišćenja uljem od 8. listopada 1991. (Narodne novine, Međunarodni ugovori, br. 1/1992), izmijenjene Protokolom objavljenim u Narodnim novinama, Međunarodni ugovori, br. 2/1997. Izmjene su na snazi u Republici Hrvatskoj od 12. siječnja 1999. godine.

66 LNG HRVATSKA d. o. o., kao ovlaštenik koncesije na pomorskom dobru u svrhu gradnje i gospodarskog korištenja industrijske luke terminal za UPP Omišalj, do isteka roka 21. prosinca 2018. godine u postupku za obvezujući zakup kapaciteta terminala, zaprimila je ponude za obvezujući zakup kapaciteta terminala od strane domaćih trgovačkih društava Hrvatske elektroprivrede d. d. i INA-e d. d., a pristigle su i uvjetne ponude za neobvezujući zakup.

67 Čl. 809. PZ-a.

68 Vidi supra 2.

69 Narodne novine, br. 35/2005, 41/2008, 125/2011, 78/2015 i 29/2018, dalje u tekstu: ZOO. 
viđaju i mogućnost oslobođenja operatera od odgovornosti ako dokaže da nije kriv. ${ }^{70} \mathrm{~S}$ druge strane, na temelju pravila o objektivnoj odgovornosti odgovara se bez obzira na krivnju ${ }^{71}$, i to u slučaju utvrđenja da je šteta prouzrokovana opasnom djelatnošću. Valja imati na umu da opisane djelatnosti u vezi s radom plutajućeg terminala nisu u nacionalnom zakonodavstvu izričito navedene kao opasne djelatnosti. Također, u samom ZOO-u ${ }^{72}$, kao uostalom ni u Nacrtu Komisije za međunarodno pravo $^{73}$, nije pobliže uređen pojam djelatnosti s povećanom opasnošću. Stoga bi nacionalnim sudovima bilo prepušteno tumačiti u svakom pojedinom slučaju je li šteta uzrokovana djelatnošću koja se smatra opasnom kako bi se utvrdila pravna osnova (objektivne) odgovornosti, a to bi nedvojbeno stvorilo pravnu nesigurnost.

Uzimajući u obzir razmjer štetnih posljedica koje djelatnosti vezane uz rad plutajućeg terminala već po samoj svojoj prirodi mogu prouzročiti, valjalo bi izričito propisati da je riječ o opasnim djelatnostima, i to u ZTUPP-u. Međutim, njegovim trenutačnim zakonskim tekstom, koji sadržava samo 16 članaka, propušteno je temeljito urediti pitanje odgovornosti za štetu, a upravo bi se tim propisom kao lex specialisom trebalo uzeti u obzir sve posebnosti opisanih djelatnosti.

U čl. 10. ZTUPP-a propisano je da je "investitor obvezan imati važeće police osiguranja kojima se osiguravaju odgovornost za štete prouzročene s terminala za UPP...". Ako bi se uz to primijenio i sustav objektivne odgovornosti operatera, doprinijelo bi se ne samo uklanjanju pravne nesigurnosti već i ostvarenju načela prevencije jer bi osiguratelji u tom slučaju tražili ispunjavanje najviših standarda zaštite morskog okoliša tijekom obavljanja predmetnih djelatnosti. Također, ostvarilo bi se i jedno od temeljnih načela zaštite i očuvanja okoliša: načelo “onečišćivač plaća”. Svrha uvođenja ovog načela u prvom je redu ekonomska kako bi se troškovi sprječavanja, smanjenja i nadziranja onečišćenja prebacili izravno na onečišćivača. Ipak, primjena ovog načela trebala bi uključiti i odgovornost države pod čijom kontrolom ili jurisdikcijom su nastale štetne posljedice djelatnosti s povećanom opasnošću. Države bi u najmanju ruku trebale osigurati da odgovorna osoba ima policu osiguranja kojom se osigurava odgovornost za štetu prouzročenu s plutajućeg terminala, a sve u svrhu ostvarenja "brze i odgovarajuće

70 Čl. 1045. st. 1. ZOO-a.

71 Čl. 1045. st. 3. ZOO-a.

72 Iako čl. 1045. st. 3. ZOO-a daje smjernicu sukladno kojoj su to takve djelatnosti “... od kojih potječe povećana opasnost štete za okolinu".

73 Vidi tekst u bilj. 61. 
naknade ili drugog načina popravljanja štete prouzročene onečišćenjem morskog okoliša koju su izazvale fizičke ili pravne osobe pod njihovom jurisdikcijom" ${ }^{74}$

Osim toga, prema mišljenju nekih autora ${ }^{75}$, trebalo bi i na međunarodnoj razini urediti pitanje građanskopravne odgovornosti za štetu zbog korištenja UPP-a kao goriva, kao što je to učinjeno za režim odgovornosti zbog onečišćenja uljem i dr. Iako će FSRU jedinica, kao što je naprijed rečeno ${ }^{76}$, koristiti prirodni plin kao gorivo koje ima određene prednosti u odnosu na korištenje konvencionalnih brodskih goriva ${ }^{77}$, ipak bi, zbog mogućih štetnih posljedica velikih razmjera koje mogu nastati uslijed izlijevanja UPP-a ${ }^{78}$, bilo opravdano na taj način urediti ovo pitanje te tako izbjeći pravnu nesigurnost uslijed različitog uređenja na nacionalnim razinama.

\section{ZAKLJUČAK}

S obzirom na različita poimanja o odabiru sredstava za ostvarenje određenih gospodarskih ciljeva, koja iz jednog kuta gledišta mogu biti opravdana, pa čak i nužna, dok iz drugoga mogu u konačnici proizvesti više štete nego koristi, u ovom slučaju u odnosu na morski okoliš postavlja se pitanje koliko su međunarodni ugovori za zaštitu morskog okoliša uistinu učinkoviti u ostvarivanju svoje primarne funkcije usmjerene na prevenciju onečišćenja. Osim toga, valjalo bi ujedno razmotriti jesu li i u kojoj mjeri međunarodni ugovori o zaštiti okoliša doprinijeli ostvarivanju još jednog načela, i to načela održivog razvitka. ${ }^{79}$ Pravno uređenje pitanja zaštite i očuvanja morskog okoliša je, u tom smislu, vrlo složeno i nužno zahtijeva interdisciplinarni pristup kako bi se svjetsko gospodarstvo razvijalo u skladu s novim znanstvenim spoznajama o morskom okolišu.

Tako među protivnicima izgradnje plutajućeg terminala ima i onih koji nisu sasvim protiv rada terminala za UPP, već smatraju boljim izborom korištenje samo kopnenog terminala. Ako se ide dalje i pokušava naći kompromisno rješenje, možda bi bilo prihvatljivije izgraditi plutajući, ali odobalni terminal

\footnotetext{
74 Čl. 235. st. 2. Konvencije iz 1982.

75 Xu, J.; Testa, D.; Mukherjee, P. K., The Use of LNG as a Marine Fuel: Civil Liability Considerations from an International Perspective, Journal of Environmental Law, vol. 29, br. 1, 2017., str. 133 - 141 .

76 Vidi supra 4.1.2.

77 Xu et al., op. cit. u bilj. 75, str. 131.

78 Vidi supra 1.

79 Doussis, E., Does International Environmental Law Matter in Sustainable Development?, Yearbook of International Environmental Law, vol. 28, 2017., str. 4 - 5 .
} 
(engl. off-shore terminal). Ne može se zanemariti činjenica da u užoj okolici od samo tri kilometra od terminala na otoku Krku živi 1550 stanovnika $^{80}$ te se unutar tog područja nalaze uređene plaže, hoteli, centar za vodene sportove i drugi sadržaji. Pomicanjem plutajućeg terminala na 10 do 15 kilometara od obale, kao što je to slučaj, primjerice, s odobalnim terminalom Adriatic LNG u Italiji ${ }^{81}$, doprinijelo bi se smanjivanju mogućih štetnih posljedica od djelatnosti s povećanom opasnošću.

Međutim, s obzirom na postojeće stanje, nakon načela prevencije kojemu je cilj spriječiti da do onečišćenja morskog okoliša uopće dođe te zatim intervencije kojom se nastoji smanjiti i nadzirati onečišćenje, preostaje staviti naglasak na utvrđivanje odgovornosti u slučaju ako i kada šteta za morski okoliš nastupi. Najbolje bi bilo u interesu oštećenika odgovornost usmjeriti na državu sukladno međunarodnom pravu ili bar detaljnije urediti dužnost države da osigura odgovarajuće mehanizme odgovornosti u slučaju nastanka štete prouzročene djelatnostima s povećanom opasnošću.

\section{LITERATURA}

\section{Knjige:}

Ćorić, D., Međunarodnopravni sustav odgovornosti i naknade štete zbog onečišćenja mora uljem, Hrvatska akademija znanosti i umjetnosti, Jadranski zavod, Zagreb, 2002.

Degan, V. Đ., Međunarodno pravo, Školska knjiga, Zagreb, 2011.

Pomorska enciklopedija, sv. 5., Mito-Pa, Jugoslavenski leksikografski zavod "Miroslav Krleža", Zagreb, 1981.

Rudolf, D., Enciklopedijski rječnik međunarodnoga prava mora, Matica hrvatska, Zagreb, 2012.

Sands, P., Principles of international environmental law I: Frameworks, standards and implementation, Manchester University Press, Manchester - New York, 1995.

Seršić, M., Medunarodnopravna zaštita morskog okoliša, Pravni fakultet Sveučilišta u Zagrebu, Zagreb, 2003.

Shaw, M. N., International Law, 4. izdanje, Cambridge University Press, Cambridge, 1997.

80 Op. cit. u bilj. 27., str. 266.

81 https://www.adriaticlng.it/ (3. prosinca 2019. godine) 


\section{Članci:}

Bakran-Petricioli, T.; Smital, T.; Petricioli, D.; Mlinarić, D., Obraštaj na plinskim platformama u Jadranu kao pokazatelj stanja okoliša, Nafta i Plin, vol. 35, br. 42, 2015., str. 72-80.

Boczek, B. A., Global and Regional Approaches to the Protection and Preservation of the Marine Environment, Case Western Reserve Journal of International Law, vol. 16, 1984., str. 39-70.

Degan, V. Đ., Internal waters, Netherlands Yearbook of International Law, vol. 17, 1986., str. 3-44; https://doi.org/10.1017/S0167676800001550

Doussis, E., Does International Environmental Law Matter in Sustainable Development?, Yearbook of International Environmental Law, vol. 28, 2017., str. 3-14; https:// doi.org/10.1093/yiel/yvy086

Koska-Legieć, A., What is the Real Issue with Floating Storage and Regasification Units? Regulations Related to the FSRU Implementation Process in the Baltic Sea, TransNav, The International Journal on Marine Navigation and Safety of Sea Transportation, vol. 12, br. 3, 2018., str. 499-503; https://doi.org/10.12716/1001.12.03.08

Seršić, M., Odgovornost za onečišćenje morskog okoliša: međunarodnopravna odgovornost država i građanskopravna odgovornost, Zbornik Pravnog fakulteta u Zagrebu, vol. 58, br. 1-2, 2008., str. 263-291.

Sucharitkul, S., State Responsibility and International Liability under International Law, Loyola of Los Angeles, International and Comparative Law Journal, vol. 18, br. 4, 1996., str. 821-839.

Xu, J.; Testa, D.; Mukherjee, P.K., The Use of LNG as a Marine Fuel: Civil Liability Considerations from an International Perspective, Journal of Environmental Law, vol. 29, br. 1, 2017., str. 129-153; https://doi.org/10.1093/jel/eqx001

\section{Međunarodni ugovori, rezolucije, zakoni i drugi propisi:}

Konvencija Ujedinjenih naroda o pravu mora, Narodne novine, Međunarodni ugovori, br. 9/2000

Konvencija o zaštiti morskog okoliša i obalnog područja Sredozemlja, Narodne novine, Međunarodni ugovori, br. 17/1998

Protokol o suradnji u sprječavanju onečišćavanja s brodova i, u slučajevima opasnosti, u suzbijanju onečišćavanja Sredozemnog mora, Narodne novine, Međunarodni ugovori, br. 12/2003

Međunarodna konvencija o nadzoru štetnih sustava protiv obraštanja brodova, Narodne novine, Međunarodni ugovori, br. 10/2006 
Međunarodna konvencija o sprječavanju onečišćenja mora s brodova, Narodne novine, Međunarodni ugovori, br. 1/1992

Međunarodna konvencija o zaštiti ljudskih života na moru, Narodne novine, Međunarodni ugovori, br. 1/1992

Prilog II: Pravila o sprječavanju onečišćenja štetnim tekućim tvarima koje se prevoze u trupu uz Međunarodnu konvenciju o sprječavanju onečišćenja mora s brodova, Resolution MEPC. 265(68)

Prilog VI: Pravila o sprječavanju onečišćenja zraka s brodova uz Međunarodnu konvenciju o sprječavanju onečišćenja mora s brodova, Resolution MEPC. 176(58)

Kodeks o gradnji i opremi brodova za prijevoz ukapljenih plinova u trupu, Resolution MSC. 5(48) i MSC. 370(93)

Međunarodna konvencija o građanskoj odgovornosti za štetu zbog onečišćenja uljem, Narodne novine, Međunarodni ugovori, br. 2/1997

Međunarodna konvencija o osnivanju Međunarodnog fonda za naknadu štete zbog onečišćenja uljem, Narodne novine, Međunarodni ugovori, br. 2/1997

United Nations, International Law Commission, Report on the work of its fifty-eight session (1 May - 9 June and 3 July - 11 August 2006), A/61/10

Zakon o terminalu za ukapljeni prirodni plin, Narodne novine, br. 57/2018

Pomorski zakonik, Narodne novine, br. 181/2004, 76/2007, 146/2008, 61/2011, 56/2013, 26/2015 i 17/2019

Zakon o obveznim odnosima, Narodne novine, br. 35/2005, 41/2008, 125/2011, $78 / 2015$ i $29 / 2018$

Zakon o zaštiti okoliša, Narodne novine, br. 80/2013, 153/2013, 78/2015, $12 / 2018$ i $118 / 2018$

Zakon o zaštiti zraka, Narodne novine, br. 127/2019

Uredba o procjeni utjecaja zahvata na okoliš, Narodne novine, br. 6l/2014 i $3 / 2017$

Uredba o standardu kakvoće voda, Narodne novine, br. 96/2019.

Uredba o kvaliteti tekućih naftnih goriva i načinu praćenja i izvješćivanja te metodologiji izračuna emisija stakleničkih plinova u životnom vijeku isporučenih goriva i energije, Narodne novine, br. 57/2017

Pravilnik o praćenju kvalitete zraka, Narodne novine, br. 79/2017

Pravila za statutarnu certifikaciju pomorskih brodova, Sprječavanje onečišćenja, Narodne novine, br. 8/2020

Plan intervencija kod iznenadnih onečišćenja mora, Narodne novine, br. 92/2008 


\section{Internetske poveznice:}

https://vijesti.hrt.hr/490883/omisalj-zagovornici-i-protivnici-lng-a

https://www.unenvironment.org/explore-topics/oceans-seas/what-we-do/addressing-land-based-pollution

http://www.imo.org/en/About/Pages/Default.aspx

https://lng.hr/lib/plugins/kcfinder/upload/files/Studija\%20o\%20utjecaju\%20 na\%20okoli\%C5\%Al\%20za\%20plutaju\%C4\%87i\%20terminal\%20za\%20 ukapljeni\%20prirodni\%20plin.pdf

https://radio.hrt.hr/radio-rijeka/clanak/eko-kvarner-replinifikacija-pomocu-mora-i-klora-iznimno-stetna-za-okolis/165731/

https://www.adriaticlng.it/ 
Summary

Irena Nišević*

\section{THE FLOATING LNG TERMINAL ON THE ISLAND OF KRIK \\ - LEGAL ASPECTS OF THE PROTECTION OF THE MARINE ENVIRONMENT WITH AN EMPHASIS ON INTERNATIONAL LAW}

This paper deals with the legal aspects of the effects of the floating terminal on the island of Krk on the marine environment during its operation, which is estimated to start on 1 January 2021, without discussing the effects of its construction.

The activities of the floating terminal include the receipt, storage and regasification of liquified natural gas along with the forwarding of natural gas to the transport system. These activities may lead to injurious consequences for the marine environment, despite the application of the standard of due dilligence. In the event that pollution of the marine environment arises from these ultra-hazardous activities, the operator of these activities bears the responsibility, unless liability of the state under whose jurisdiction or control the activities are carried out has been expressly agreed to in the contract under which the operator is authorised to undertake such activities.

Keywords: floating terminal; liquified natural gas; pollution of the marine environment; ultra-hazardous activities; state liability

* Irena Nišević, LL. M., Assistant, Adriatic Institute of the Croatian Academy of Sciences and Arts, Augusta Šenoe 4, Zagreb; irena.crnjak@gmail.com;

ORCID ID: orcid.org/0000-0002-8763-8159 
